\title{
A KEY TO THE GENERA OF THE SUBFAMILY APHIDINAE AND NOTES ON SYNONOMY.
}

By H. F. Wilson,

Oregon Agricultural College.

The following paper is not as complete as the author would like to have it as type species of four recently formed genera are not available. Several attempts have been made to secure the desired species without success and as there does not seem to be much chance of securing them in the near future copies of the original keys are included in this paper. All of them were made by Del Guercio and three of them are given as a division of the so called genus Aphis.

The first three are given in Redia (vol. 4, pp. 190-192, 1907) with the following key.

1. Femine partenogeniche attire ed alate sprovviste di codetta o con questa affatto rudimentale.

Gen. Anuraphis Del Guercio

(Sp. tip. Aphis pyri Koch).

Femmine attere ed alate con codetta distinta..............2

2. Codetta costantamente piu corta dei sifoni.

Gen. ApHis Linne

(Sp. tip. Aphis sambuci L.)

Codetta constantamente eguale, o piu lunga dei sifoni.......3.

3. Codetta piu lunga dei sifoni.

Codetta della stessa lunghezza dei sifoni.

Gen. Uraphis Del Guercio

(Sp. tip. Aphis genistae Kalt.)

Gen. Microsiphon Del Guercio

(Sp. tip. A phis tormentillae Pass.)

The fourth was published two years later (Rivista di patologia X Vegetale anno IV Num. 11. Agosto 1909. pp. 4-5.) This species is given as the dividing line between Anuraphis Del Guercio and Myzus Passerini.

A. Codetta verricuforme, rudimentale o nulla.

I. Femmine attere con tubercoli frontali nulli, in ogni caso evidentemente piu corti della meta della fronte; antenne corte col primo articolo subeguale al secondo.

Gen. Anuraphis Del Guercio.

II. Femine attere con tubercoli frontali piu lunghi della meta del margine della fronte fra essi compressa: primo articolo del antenne, che sono lunghe, due volte piu lungo del secondo.

AA. Codetta hen distinta Gen. Macchiatiella Del Guercio.

Gen. Myzus Passerini. 
In working up synonomy from a standpoint of literature there seems to be a great difference of opinion. However since an International Code has been established there seems to be but one correct plan and if followed in all cases the troubles of the systematist must soon disappear. One of the rules of the code in substance states that if a number of species belonging to distinct different genera are arranged under a certain genus without a type being set by the maker of the genus then the type may be any one of the original species. If all the species but one are removed without a type being set then the last species is the type.

In 1758 Linnaeus formed the genus Aphis without setting a type. In this genus he included a large number of species which have been placed in various different genera, and Aphis sambuci is now generally taken as the type of the original

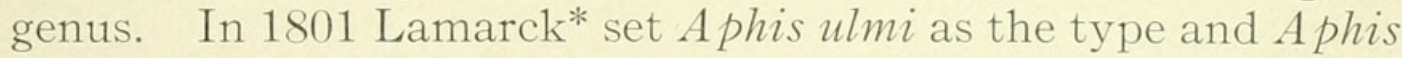
sambuci was not set until a year later by Latreille. $\dagger$

Aphis ulmi L. is the species generally known as Tetraneura ulmi DeGeer. This species was first described and figured by Reaumer previous to the 10th Edition of Linnaeus. Linnaeus and DeGeer give the same citation, so the species does not belong to DeGeer. Schizoneura ulmi Linn. is the species designated by himself as Chermes ulmi.

The author of this paper will not at this time attempt to say that any of the above names should be changed, but it seems that a decision of some kind as to the disposal of the above should be made.

In making the key type species of each genera were used and more or less detailed descriptions taken of the external characters. In several instances wide variations were noticed among the species included in certain genera and some were separated to form new genera.

In studying closely related genera the development of external characters may be placęd in five divisions. 1. The antennae and spur. 2. The antennal tubercles. 3. The development of the nectaries. 4. The development of the cauda. 5. The development of the wing venation. In a group of insects as pliable as the present one, any one or two of these characters

Systeme des animaux sans vertebres, ou Tab. gen. classes, des orders et generes animaux A. Paris, an. IX, p. 300 . 1801 .

† Histore Naturelle Gen. et par. Des Crus. èt Ins. Tome III, p. 264. 1802. 
may be either under or over developed and it is necessary to place the genera according to the greatest development. Of all the characters which show this variation the wings show what may be true of all the characters.

Along these lines the subfamily has been divided into three tribes as follows:

A. Nectaries nearly as long as the body and with long hairs...... Trichosiphini.

- Nectaries without hairs and not more than half as long as the body ......... B.

B. Nectaries variable in length but at least one fourth the length of the body. Antennae as long as the body or longer and set on distinct antennal tubercles. The antennae of Phorodon are shorter but the tubercles are greatly developed.

Macrosiphini.

- Nectaries variable in length; antennae usually shorter than the body and not set on distinct antennal tubercles. When tubercles are present antennae and nectaries are much reduced

Aphidini.

\section{Tribe TrichosIPHINI}

This tribe is limited to two genera both of which are found in the Asiatic Islands. The nectaries are quite remarkable in that they are covered with long hairs. In other respects they are not so different from the genera of the other two tribes.

I. Antennae not longer than the body and the cubital vein twice forked.

II. Antennae longer than the body and the cubital vein with but one fork.

Trichosiphum.

Greenidea.

\section{Gen. Trichosiphum Pergande}

type anonae Pergande.

Antennae about as long as the body, six, segmented, and fixed on large tubercles; spur of sixth segment shorter than third segment; first segment gibbous. Antennal tubercles slightly tapering but not gibbous being oblique to the forehead which is nearly flat. Body elongate and narrow; stigma of wing long and slender; cubitus twice forked. Nectaries as long as the body cylindrical, and standing out at right angles to the body. Cauda short and triangular; anal plate short, half moon shaped. Antennae, legs, and nectaries as well as the body covered with long bristle like hairs.

Apterous female:-Body short, robust, with antennae one half the length of the body; six segmented, with small antennal tubercles. Nectaries one fourth the length of the body and vasiform. Cauda short and broadly rounded; anal plate broad and slightly emarginated at the center. Antennae, nectaries, legs and body exceedingly hairy. 


\section{Gen. Greenidea Schouteden.}

type S. artocarpi Westwood.

Antennae longer than the body and six segmented; spur of sixth shorter than the third segment; first segment slightly gibbous on the inner side. Antennal tubercles large and tapering, front of head wide and flat. Body long and slender, wings long, venation variable but usually the cubitus is but once forked. Nectaries almost as long as the body, slender and nearly cylindrical. Cauda short, broader than long and rounded at the tip; base slightly constricted; anal plate rounded. Body and appendages exceedingly hairy.

\section{Tribe Macrosiphini}

The author has divided this group from the following in order that the key may not contain too many conflicts. The division is made between species having distinct antennal tubercles and those having none or at the most indistinct tubercles. However should a certain species have distinct antennal tubercles with the other characters wanting then it would have to go in the next tribe.

I. Antennal tubercles tapering and very large, not gibbous on the inner side.

Antennal tubercles gibbous or toothed on the inner side

II. Nectaries nearly half as long as the body, cylindrical and curved... Illinoia. Nectaries at least one fourth the length of the body and vasiform.

Nectarosiphon.

III. Antennal tubercles large, and as long on the outer side as on the inner; upper inner angle more or less gibbous. Nectaries variable.......... IV. Antennal tubercles prominent but not large and the inner side longer than

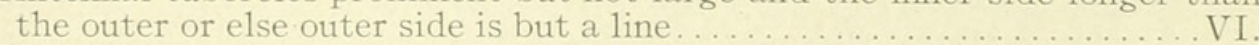

IV. Nectaries tapering longer than the cauda which is sickle shaped. Wings regular with twice forked cubitus....................... Nectaries and cauda variable, wing venation irregular but very striking. Veins either wanting or else combined.

V. Antennal tubercles with sharp upper inner angle, cauda shorter than the nectaries and tapering. Stigmal and cubital vein almost meet in a broad dark band, giving the wing the appearance of having a closed triangular cell.

Idiopterus. Antennal tubercles with small round tubercle at upper inner angle. Nectaries tapering and slightly longer than tapering cauda. Wing venation variable but usually with the cubitus once forked, and the hind wing with but a single oblique vein .

Microparsus.

Antennal tubercle with small rounded tubercle at upper inner angle. Nectaries constricted at the middle and tip. Wing venation variable but usually the stigmal and cubital veins are partly joined and form a distinct closed cell with four sides.

Pentalonia.

VI. Antennal tubercles short but not wedge shaped. Cauda large and long. VII.

Antennal tubercles wedge shaped with the inner side formed into a tubercle

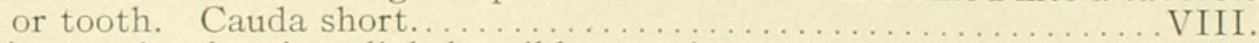

VII. Antennal tubercles slightly gibbous. Antennae much longer than the body, nectaries strongly clavate. Wings with cubitus twice forked. 
Antennal tubercles as in the above genus. Nectaries tapering, wings with the cubital vein having but a single fork................... Toxoptera

VIII. Antennal tubercles with a strong tooth on the inner side. Nectaries almost cylindrical but tapering slightly. Cauda short and tapering.

Phorodon

- Antennal tubercles with a prominent blunt projection forming the inner side. Nectaries slightly clavate, cauda tapering and with a knobbed tip.

Rhopalosiphum

Antennal tubercles with a distinct but not prominent blunt projection forming the inner side of the tubercle (more prominent in the apterous forms). Nectaries cylindrical and slightly curved at tip. Cauda short and tapering, being almost triangular in form.

Myzus

\section{Gen. Illinoia new genus}

\section{type $M$. liriondri Monell}

Antennae longer than the body, six segmented, and situated on prominent tubercles; spur of sixth segment as long or longer than the third; first segment strongly gibbous on inner side. Antennal tubercles and inner side not gibbous but tapering. Body elongate, wings long and medium stout; cubitus twice forked. Nectaries almost as long as the abdomen, broad at the base and tapering, being strongly constricted for a short distance back of the tip. Tip curved outwardly. Cauda ensiform, about one third the length of the abdomen and constricted in the middle. Anal plate broad and bluntly angled.

\section{Gen. Nectarosiphon Schouteden}

type $M$. rubicola Oestlund.

Antennae longer than the body, six segmented, and placed on fairly prominent tubercles; spur of sixth segment shorter than the third segment, first joint slightly gibbous on inner side. Front of head flat and narrow, Body elongate, wings large, nectaries about one fourth the length of the body with distal half dilated. Cauda one half the length of the nectaries and tapering. Anal plate triangular.

\section{Gen. Macrosiphum Passerini}

type $A$. rosae Linn.

Antennae six segmented, longer than the body and situated on fairly prominent tubercles; spur of sixth segment longer than third, first segment about as long as broad. Antennal tubercles slightly gibbous on the inner side. Inner surfaces at right angles to the head; forehead flat. Wings long, cubitus with two forks. Nectaries about one fourth the length of the body and tapering. Cauda as long as the nectaries and ensiform. 


\title{
Gen. Idiopterus Davis
}

\author{
type nephrelepidis Davis.
}

Antennae about one and a half times as long as the body and placed on prominent tubercles; segments one and two large, the remaining segments long and slender, spur of sixth segment longer than the third. Antennal tubercles much larger than the second segment and with the upper inner side sharply angled. Body elongated, wings with the stigmal vein deeply rounded almost touching the discoidal and both lying in a broad dusky band. This gives the wing the appearance of having a closed triangular cell. Nectaries about one fifth the length of the body, straight and cylindrical. Cauda nearly as long as the nectaries and tapering.

\section{Gen. Microparsus Patch}

type variabilis Patch.

Antennae longer than the body and placed on prominent tubercles, spur of sixth segment longer than the third. First segment large and gibbous on the inner side. Antennal tubercles close together, head flat in front and merging into the tubercles. Wings long, cross veins heavy and cubitus usually with a single fork; stigma long and slender, hind wing with but a single cross vein. Nectaries about one fifth the length of the body and tapering. Cauda as long as the nectaries and broadly tapering. Anal plate slightly broader than the base of the cauda and triangular.

\section{Gen. Pentalonia Coquerel}

type nigronervosa Coq.

Antennae slender, longer than the body and placed on prominent tubercles; spur of sixth segment longer than the third, first segment strongly gibbous. Antennal tubercles gibbous at the upper inner edge. Body short and robust, wings long and with the oblique veins nearly at right angles to the costa; cubitus twice forked and at or slightly beyond the second fork combines with the radial sector, thus forming a closed cell; veins dark, hind wing with but a single cross vein. Nectaries about one-fifth the length of the body, and constricted in the middle and just behind the tip. Cauda but a knob situated on a broad base as in Callipterini. Anal plate broad with apex parallel to the base. 


\title{
Gen. Amphorophora Buckton
}

\author{
type ampullata Buckton.
}

Antennae longer than the body and placed on prominent tubercles, third segment shorter than the spur of the sixth; first segment slightly gibbous on the inner side. Antennal tubercles on inner side rounded. Head broad in front and almost flat. Body elongate, abdomen stout. Wings large and regular, nectaries about one fourth the length of the body and very strongly vasiform. Cauda two thirds the length of the nectaries and tapering. Some species with cauda constricted about the middle.

\section{Gen. Toxoptera Koch}

type aurantiae Koch.

Antennae about as long as the body and placed on small but distinct tubercles, third segment shorter than the spur of sixth; first segment gibbous on the inner side. Body elongate, wings long and slender with the cubital vein having but a single fork. Nectaries one sixth the length of the body and cylindrical. Cauda nearly as long as the nectaries and ensiform. Anal plate broadly rounded.

\section{Gen. Phorodon Passerini}

\section{type $A$. humuli Schrank}

Antennae nearly as long as the body and placed on prominent tubercles, third segment longer than the spur of the sixth; first segment strongly gibbous. Antennal tubercles bearing a long tooth on the inner side, in the apterous forms this is more developed. Forehead narrow with a small tubercle bearing a frontal ocellus. Body elongate, wings long and broad with cubitus twice forked. Nectaries about one sixth the length of the body, cylindrical, and with a slight taper at the base. Cauda one half the length of the nectaries, broad at the base and tapering to a sharp point. Anal plate broadly rounded.

\section{Gen. Rhopalosiphum Koch}

\section{type $A$. persicae Sulzer.}

Antennae slightly longer than the body and placed on prominent wedge shaped tubercles, third segment about the same length as the spur of the sixth; first segment gibbous on the inner side. Antennal tubercles with a blunt tooth on the 
inner side, the whole tubercle appearing as a wedge inserted between the head and the first antennal segment. Forehead narrow, outer edge of tubercles appear constricted. Body elongated, wings long. Nectaries about one fourth the length of the body and clavate at the outer end, cauda short, anal lobe broadly rounded.

\section{Gen. Myzus Passerini}

type A. cerasi Fabricius.

Antennae about as long as the body and situated on distinct tubercles, third segment as long as spur of sixth; first segment strongly gibbous. Antennal tubercles strongly gibbous on the inner side. Body robust, wings long and broad with cubitus twice forked. Nectaries about one fourth the length of the body, cylindrical, slightly constricted near the tip and slightly curved outward. Cauda less than half the length of the nectaries and tapering. Anal plate broadly rounded.

\section{Tribe ApHIDINI}

The characters which separate this tribe from the previous are taken as follows. Antennae shorter than the body, or when as long as the body nectaries and cauda very short. Antennal tubercles, when present, are indistinct or else the nectaries and cauda are small. When nectaries are very long or large the development is limited and the other characters are used to place the genera. Liosomaphis has large nectaries but the antennae and cauda are very short. Mastopoda has the antennae more developed than other genera but the tubercles are wanting.

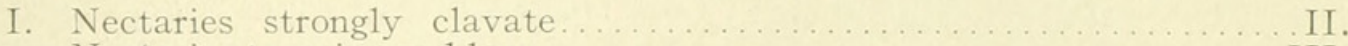

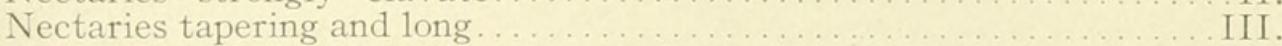

Nectaries cylindrical and long............................

Nectaries very short or obscure ..............................

II. Antennae shorter than the body, spur of sixth segment not longer than third segment. Nectaries long and strongly clavate on one side.

Liosomaphis

Antennae slightly shorter than the body and with the spur of sixth segment much longer than third segment. Nectaries slightly swollen throughout

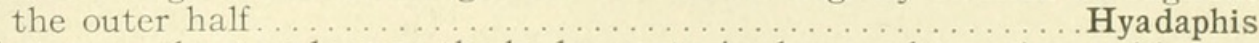

III. Antennae about as long as the body, nectaries long and tapering and longer

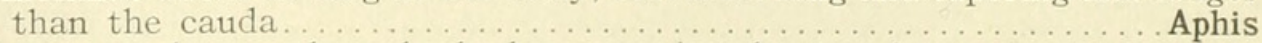
Antennae shorter than the body, nectaries short and tapering and nearly half as wide as long. Cauda short but as long as the nectaries.

Pergandeida

IV. Antennae as long as the body, nectaries nearly one fourth the length of the body. Tarsi and claws atrophied................................. 
Antennae much shorter than the body, nectaries slightly constricted at the tip

Coloradoa

Antennae shorter than the body and with but five segmented antennae. Nectaries short and cylindrical.

V. Nectaries prominent and readily distinguishable.

VI. Antennae shorter than the body, nectaries very st

Cerosipha short and thick. VII.

Antennae shorter than the body, nectaries very short in above but slender and swollen in the middle.

Hyalopterus

VII. Antennae much shorter than the body, nectaries cylindrical and as broad as long. Cauda much longer than the nectaries and tapering. Brachycolus Antennae longer than the body, nectaries barely distinguishable, the end being trumpet shaped. Cauda not as long as wide and triangular.

Microsiphum

Antennae shorter than the body, nectaries little more than raised rings, and not flanged like the preceding genus.

Cryptosiphum

\section{Gen. Liosomaphis Walker}

\section{type A. berberidis Kaltenbach}

Antennae shorter than the body and with indistinct antennal tubercles, spur of sixth segment about the same length as the segment; first segment gibbous on the inner side. Body elongate, abdomen robust, wings long and broad, cubitus twice forked. Nectaries about one fourth the length of the body and strongly clavate. Cauda less than one half the length of the nectaries and sharply tapering. Anal plate broadly rounded.

\section{Gen. Hyadaphis Kirkaldy}

Syn. Siphocoryne passerini preoccupied.

Antennae nearly as long as the body, third segment shorter than the spur of the sixth. Head with a slight projection at the inner base of each antenna. Body elongate, wings long and broad, venation regular. Nectaries about one fourth the length of the body and clavate in the middle. Cauda triangular short and rounded at the tip. Anal plate broad half moon shaped.

\section{Gen. Aphis Linnaeus}

\section{type A. sambuci Linn.?}

Antennae as long as the body, spur of sixth segment three times as long as the segment and as long as the third segment. Body elongated, abdomen robust. Wings broad and stout, with cubitus twice forked. Nectaries about one fourth the length of the body, somewhat slender and tapering. Cauda one fourth the length of the nectaries, stout and set on a broad base. Tip broadly rounded. 


\section{Gen. Mastopoda Oestlund}

type pteridis Oestlund.

Antennae about as long as the body, third segment shorter than the spur of the sixth; first segment gibbous on the inner side. Forehead nearly flat, body elongate, abdomen robust. Wings long and slender, nectaries about one fourth the length of the body and cylindrical. Cauda very short and conical, anal plate broadly rounded. The atrophied tarsi and claws of this genus are the most distinguishing characters.

\section{Gen. Coloradoa new genus}

type $A$. rufomaculata Wilson.

Antennae about two thirds the length of the body, third segment longer than the spur of the sixth which is only about twice as long as the sixth. Wings moderately long, nectaries one sixth as long as the body, cylindrical at the base and slightly clavate at the end as in Rhopalosiphum. Cauda two thirds as long as the nectaries and tapering; tip blunt. Caudal plate broadly rounded.

\section{Gen. Cerosipha Del Guercio}

\section{type passerinina Del Guerc.}

Antennae shorter than the body and with but five segments and spur, third segment longer than the spur of the fifth. Forehead nearly flat but slightly raised in the center. Body elongate, abdomen the widest part of body. Wings long, medium wide, wing venation regular with twice forked cubitus. Nectaries about one tenth the length of the body and cylindrical, with a very slight taper. Cauda slightly shorter than the nectaries and tapering to a round point.

\section{Gen. Pergandeida Schouteden}

type ononidis Schout.

Antennae about as long as the body, spur of sixth segment as long as the third segment. Forehead with a prominent tubercle supporting the frontal ocelli, and slightly raised at the base of the antennae. Body elongated, stout; wings low and broad with twice forked cubitus. Nectaries short stout and tapering. Cauda as long as nectaries and broadly rounded at the tip. Anal plate broadly rounded. 


\section{Gen. Hyalopterus Koch}

type aurantiae Koch.

Antennae shorter than the body, third segment as long as the spur of the sixth; first segment strongly gibbous on the inner side. Frontal ocelli prominent, forehead slightly raised at the base of each antenna. Body long and slender, wings also long and slender with cubitous twice forked. Nectaries very short and slender, being slightly swollen in the middle. Cauda twice as long as the nectaries and tapering to a blunt point, slightly constricted near the middle. Anal plate broadly rounded.

\section{Gen. Brachycolus Buckton}

type A. stellariae Hardy.

Antennae shorter than the body, third segment as long as the spur of the sixth; first antennal joint slightly gibbous. Body slender, wings long and slender and with the cubitus twice forked. Nectaries very short, being as long as broad and cylindrical. Cauda about twice as long as the nectaries and slender, tapering to a blunt point. Anal plate rounded and not distinct from the body.

\section{Gen. Microsiphum Cholodkovsky}

type ptarmicae Cholod.

Antennae about as long as the body and set on distinct tubercles, spur of sixth segment six times as long as the segment and longer than the third segment, first segment slightly gibbous on the inner side. Forehead broad, body large and robust. Wings long and broad, cubitus twice forked. Nectaries very short, being slightly shorter than the second antennal segment and flanged at the end like that of a horn. Cauda wide, exceedingly short and triangular in form. Anal plate barely distinguishable as a broad elevation. The only American form of this genus is the species which T. A. Williams called Cryptosiphum canadense, taken on Artemisae ludovicianae.*

*Special Bull. No. 1. Dept. of Entomology, University of Nebraska, July 8, 1891. 


\section{Gen. Cryptosiphum Buckton}

type artemisae Buck.

Antennae shorter than the body, spur of sixth segment shorter than the third segment and about one and one half times as long as the sixth. Forehead flat, frontal ocelli not - prominent. Body robust, wings long with the cubitus twice forked. Nectaries little more than pores with the edges slightly raised. Cauda short and tapering, anal plate rounded.

All of the genera given in this paper may be found with the original citation listed in the Entomological News for April 1910, pp. 147-156. 


\section{$2 \mathrm{BHL}$ Biodiversity Heritage Library}

Wilson, H. F. 1910. "Key to the genera of the subfamily Aphidinae and notes on synonymy." Annals of the Entomological Society of America 3, 314-325. https://doi.org/10.1093/aesa/3.4.314.

View This Item Online: https://www.biodiversitylibrary.org/item/38713

DOI: https://doi.org/10.1093/aesa/3.4.314

Permalink: https://www.biodiversitylibrary.org/partpdf/8698

\section{Holding Institution}

Smithsonian Libraries

\section{Sponsored by}

Smithsonian

\section{Copyright \& Reuse}

Copyright Status: NOT_IN_COPYRIGHT

This document was created from content at the Biodiversity Heritage Library, the world's largest open access digital library for biodiversity literature and archives. Visit BHL at https://www.biodiversitylibrary.org. 